\title{
PENERAPAN MODEL PEMBELAJARAN KOOPERATIF TIPE NUMBERED HEADS TOGETHER (NHT) DITINJAU DARI AKTIVITAS BELAJAR SISWA KELAS VIII SMP
}

\author{
MUHAMAD FIRDAUS \\ Program Studi Pendidikan Matematika IKIP PGRI Pontianak, \\ Jl. Ampera No. 88 Pontianak \\ Hp: 085245387972, e-mail: kiranafirdiani@gmail.com ${ }^{1}$
}

\begin{abstract}
Abstrak. Tujuan dari penelitian ini adalah untuk mengetahui hasil belejar siswa SMP setelah diterapkan model pembelajaran kooperatif tipe NHT yang ditinjau dari aktivitas belajar. Bentuk penelitian yang digunakan adalah Quasy Eksperiment dengan rancangan desain faktorial 1x3. Populasi dalam penelitian ini adalah seluruh siswa kelas VIII SMP Negeri 1, sedangkan sampel adalah kelas VIII-D yang dipilih secara random menggunakan teknik cluster random sampling. Alat pengumpul data yang digunakan adalah instrumen tes yang terdiri dari 4 soal essay dan angket aktivitas yang terdiri dari 23 soal. Berdasarkan uji analisis anava satu jalan dengan sel tak sama diperoleh (1) hasil belajar siswa dengan kategori aktivitas tinggi sama baiknya dengan siswa dengan kategori aktivitas sedang. (2) hasil belajar siswa dengan kategori aktivitas sedang lebih baik dengan siswa dengan kategori aktivitas rendah. (3) hasil belajar siswa dengan kategori aktivitas tinggi lebih baik dengan siswa dengan kategori aktivitas rendah.
\end{abstract}

Kata Kunci: Pembelajaran kooperatif tipe NHT, aktivitas belajar

\begin{abstract}
The purpose of this study was to find out the results belejar junior high school students after application of cooperative learning model NHT the terms of the learning activities. Forms of research is quasy Experiment with the design of a $1 \times 3$ factorial design. The population in this study were all students of class VIII SMP Negeri 1, while the sample is a class VIII-D randomly selected using random cluster sampling technique. Data collection tool used is a test instrument that consists of four essay and activity questionnaire consisting of 23 questions. Based on analysis test, one way ANOVA with different cells obtained by (1) the learning outcomes of students with high activity category as well as students with moderate activity category. (2) the learning outcomes of students with moderate activity category better with students with low activity category. (3) the learning outcomes of students with high activity category better with students with low activity category.
\end{abstract}

Keywords: Cooperative learning NHT type, learning activities

\section{PENDAHULUAN}

Dalam proses pembelajaran matematika model yang digunakan oleh guru sangat mempengaruhi hasil belajar siswa, hal ini dikarenakan model pembelajaran yang digunakan merupakan penentu keberhasilan belajar matematika dan dapat mencapai kriteria ketuntasan minimal (KKM). Namun pada kenyataannya tidak jarang kita jumpai bahwa dalam proses pembelajaran yang berperan lebih aktif adalah guru, sedangkan siswa hanya sekedar menerima informasi dan kurang berperan aktif. Padahal semestinya yang terlibat aktif itu adalah siswa, guru hanya berperan sebagai fasilitator dan motivator 
saja. Menurut Slameto (2003: 54) faktor-faktor yang mempengaruhi hasil belajar siswa dapat digolongkan menjadi dua, yaitu faktor internal dan faktor eksternal.Menurut Mulyono (Ristika, 2007: 5), penyebab utama masalah belajar yang dialami anak didik antara lain adalah faktor eksternal yaitu berupa model pembelajaran yang keliru. Oleh karena itu, dibutuhkan model pembelajaran yang tepat untuk menciptakan siswa yang aktif dan hasil belajar yang diharapkan dapat tercapai.

Salah satu model pembelajaran yang melibatkan peran siswa secara aktif adalah model pembelajaran kooperatif. Menurut Lie (2010: 12) pembelajaran kooperatif atau cooperative learning adalah sistem pengajaran yang memberi kesempatan kepada anak didik untuk bekerja sama dengan sesama siswa dalam tugas-tugas yang terstruktur, dimana dalam sistem ini guru bertindak sebagai fasilitator".Model pembelajaran kooperatif sangat cocok diterapkan pada pembelajaran matematika karena model pembelajaran ini siswa dapat mengemukakan pemikirannya, saling bertukar pendapat, saling bekerjasama, sehingga hal ini dapat meningkatkan aktivitas dan motiva sisiswa untuk mengkaji dan menguasai materi matematika yang nantinya akan meningkatkan pemahaman siswa. Pembelajaran kooperatif merupakan strategi yang menempatkan siswa belajar dalam kelompok-kelompok kecil yang beranggotakan $4-5$ orang siswa yang bersifat heterogen. Heterogen maksudnya adalah terdiri dari beragam kemampuan siswa, jenis kelamin, serta tingkat aktivitas belajar yang berbeda-beda. Ada beberapa tipe pembelajaran kooperatif yang dapat dipilih, salah satu diantaranya adalah pembelajaran kooperatif tipe NHT.

Pembelajaran kooperatif tipe NHT adalah suatu pembelajaran yang dikembangkan untuk melibatkan lebih banyak siswa dalam menelaah suatu materi pembelajaran, yaitu dengan cara memberikan nomor kepada setiap siswa, kemudian guru mengajukan pertanyaan kepada siswa untuk difikirkan bersama dalam kelompoknya dan guru memanggil salah satu nomor untuk menjawab pertanyaan yang diajukan untuk seluruh kelas.

Model pembelajaran kooperatif tipe NHT ini lebih banyak aktivitas siswa dalam menelaah materi yang tercakup dalam suatu pembelajaran dan siswa diajarkan untuk bertanggung jawab terhadap tugas yang diberikan oleh pendidiknya karena pada pembelajaran kooperatif tipe NHT siswa dalam kelompok diberi nomor yang berbeda. Setiap siswa dibebankan untuk menyelesaikan satu soal yang sesuai dengan nomor anggota mereka. Tetapi pada umumnya mereka harus mampu mengetahui dan menyelesaikan semua soal yang diberikan oleh guru. Misalnya siswa dengan nomor urut 1 dalam kelompoknya mempertanggungjawabkan soal nomor 1 begitu pula dengan siswa dengan nomor urut 2 dan seterusnya. Walaupun pada saat persentase mereka bisa ditunjuk untuk mengerjakan soal nomor lain.

Namun pada kenyataannya di lapangan menunjukkan bahwa pembelajaran dengan menggunakan model kooperatif tipe NHT masih jarang dilaksanakan guru dalam pembelajaran matematika di kelas. Kenyataan ini juga terjadi dalam pembelajaran matematika di SMP Negeri 1 Balai, sehingga siswa lebih cendrung mendengarkan saja penjelasan guru berkaitan dengan materi yang diberikan, terutama pada materi luas permukaan limas. Selain itu pula diperoleh informasi bahwa siswa sering melakukan kesalahan dalam menyelesaikan soal-soal yang ada dikarenakan siswa kurang dapat mengingat cara penyelesaian masalah luas permukaan limas segiempat yang bervariasi dan kurangnya aktivitas belajar siswa dalam proses pembelajaran berlangsung.

Salah satu usaha yang dapat dilakukan untuk meminimalkan masalah ini adalah dengan menerapkan model pembelajaran yang tepat sehingga dapat meningkatkan hasil belajar siswa dan pada akhirnya tercapailah indikator-indikator yang diharapkan serta meningkatnya kualitas belajar di sekolah. 
Dalam penelitian ini yang membedakan penelitian ini dengan penelitian yang terdahulu adalah peneliti akan melihat hasil belajar dengan berdasarkan hasil postest setelah diberikan perlakukan dengan menggunakan model kooperatif NHT sebagai variabel bebas dan juga peneliti akan menggunakan kuesioner/angket aktivitas belajar siswa sebagai variabel bebas lainnya yang juga sangat berpengaruh pada hasil belajar siswa.

\section{TINJAUAN PUSTAKA}

\section{Model Pembelajaran Numbered Head Togather (NHT)}

Dalam penelitian ini model yang akan digunakan peneliti adalah model NHT. Menurut Hamdani (2010 :89) Pembelajaran kooperatif tipe NHT adalah metode belajar dengan cara setiap siswa diberi nomor dan dibuat suatu kelompok, kemudian secara acak, guru memanggil nomor dari siswa. Lie (2010: 59) menyatakan bahwa model pembelajaran kepala bernomor (Numbered Heads) dikembangkan oleh Spencer Kagan. Karena model ini memberikan kesempatan siswa untuk saling membagikan ide-ide dan mempertimbangkan jawaban yang paling tepat. Selain itu, model ini juga mendorong siswa untuk meningkatkan semangat kerja sama mereka.

Menurut Trianto (2010: 82) langkah-langkah yang digunakan dalam pembelajaran kooperatif tipe NHT adalah:

1. Fase 1: Penomoran (Numbering)

Dalam fase ini guru membagi siswa kedalam kelompok 3-5 orang dan kepada setiap anggota kelompok diberi nomor sehingga tiap siswa memiliki nomor yang berbeda.

2. Fase 2: Mengajukan Pertanyaan (Questoining)

Guru mengajukan pertanyaan kepada siswa. Pertanyaan dapat bervariasi dari yang bersifat spesifik hingga yang bersifat umum.

3. Fase 3: Berfikir Bersama (Heads Together)

Siswa menyatukan pendapatnya terhadap jawaban dari pertanyaan itu dan meyakinkan tiap anggota dalam timnya mengetahui jawaban tim.

4. Fase 4: Pemberian Jawaban (Answering)

Guru memanggil satu nomor tertentu, kemudian siswa yang nomornya sesuai dengan yang dipanggil oleh guru mengacungkan tangannya dan mencoba menjawab pertanyaan untuk seluruh kelas.

Adapun langkah-langkah yang digunakan dalam model NHT adalah:

a. Siswa dibagi dalam beberapa kelompoknyang terdiri dari $4-5$ orang.

b. Tiap anggota diberi nomor.

c. Guru memberikan masalah/pertanyaan/LKS kepada siswa.

d. Siswa diberi waktu berfikir dan bekerja.

e. Siswa duduk secara berhadap-hadapan.

f. Setiap siswa memberi pendapat dalam kelompok.

g. Guru berkeliling kelas membimbing siswa saat bekerja kelompok.

h. Kelompok menentukan jawaban dari hasil diskusi.

i. Guru memanggil nomor siswa untuk memberi jawaban dari pertanyaan yang telah diberikan.

j. Guru memberi penghargaan kepada anggota kelompok yang berhasil menjawab pertanyaan dengan baik.

\section{Aktivitas Belajar Siswa \\ Pengertian Aktivitas belajar}

Pada prinsipnya belajar adalah berbuat. Berbuat untuk mengubah tingkah laku dengan melakukan kegiatan seperti belajar. Tidak ada belajar kalau tidak ada aktivitas. 
Itulah sebabnya aktivitas merupakan prinsip atau asas yang sangat penting di dalam interaksi pembelajaran. Aktivitas belajar adalah suatu proses kegiatan belajar siswa yang menimbulkan perubahan-perubahan. Menurut James O Wittaker (dalam sardiman, 2011: 96) aktivitas belajar adalah proses dimana tingkah laku ditimbulkan atau diubah melalui latihan atau pengalaman seseorang.

\section{Prinsip-Prinsip Aktivitas Belajar Siswa}

Prinsip-prinsip aktivitas dalam belajar dalam hal ini akan dilihat dari sudut pandang perkembangan konsep jiwa menurut ilmu jiwa. Dengan melihat unsur kejiwaan sesorang subyek belajar/ subyek didik, dapatlah diketahui bagaimana prinsip aktivitas yang terjadi dalam belajar itu. Karena dilihat dari sudut pandang ilmu jiwa, maka sudah barang tentu yang menjadu fokus perhatian adalah komponen manusiawi yang melakukan aktivitas dalam proses pembelajaran, yakni siswa dan guru.

Untuk melihat prinsip aktivitas belajar dari sudut pandangan ilmu jiwa ini secara garis besar dibagi menjadi ilmu lama dan ilmu jiwa modern sebagai berikut :

a. Menurut Pandangan Ilmu Jiwa Lama

John locke dengan konsepnya tabularasa, mengibaratkan jiwa (psyche) seseorang bagaikan kertas putih yang tidak tertulis. Kertas putih ini kemudian akan mendapatkan coretan atau tulisan dari luar. Siswa diibaratkan kertas putih, sedang unsur dari luar yang menulis adalah guru. Dalam hal ini terserah kepada guru, mau dibawa kemana, mau diapakan siswa itu, karena guru adalah yang memberi dan mengatur isinya. Dengan demikian aktivitas didominasi oleh guru, sedang anak didik bersifat pasif dan menerima begitu saja. Guru menjadi seorang yang adikuasa di dalam kelas.

Selanjutnya hobert memberikan rumusan bahwa jika adalah keseluruhan tanggapan yang secara mekanis dikuasai oleh hukum-hukum asosiasi atau dengan kata lain dipengaruhi oleh unsur -unsur dari luar. Relevansinya dengan konsep John Locke. Bahwa guru pulalah yang aktif, yakni menyampaikan tanggapan-tanggapan itu. Siswa dalam hal ini pasif, secara mekanis hanya menuruti alur dari hukum-hukum asosiasi. Jadi siswa kurang memiliki aktivitas dan kreativitas.

Mengombinasikan dua konsep yang baik dikemukakan John locke maupun Herbert, jelas dalam proses mengajar guru akan senantiasa mendominasi kegiatan. Siswa terlalu pasif, sedang guru aktif dan segala inisiatif datang dari guru. Siswa ibarat botol kosong yang diisi air oleh sang guru. Gurulah yang menentukan bahan dan metode, sedang siswa menerima begitu saja. Aktivitas anak terutama terbatas pada mendengarkan, mencatat, menjawab pertanyaan bila guru memberikan pertanyaan. Mereka para siswa hanya bekerja karena atas perintah guru, menurut cara yang ditentukan guru, begitu juga berpikir menurut yang digariskan oleh guru. Memang sebenarnya anak didik itu tidak pasif secara mutlak, hanya proses pembelajaran semacam ini jelas tidak mendorong anak didik untuk berpikir dan beraktivitas. Yang banyak beraktivitas adalah guru dan guru dapat menentukan segala sesuatu yang dikehendaki. Hal ini udah barang tentu tidak sesuai dengan hakikat pribadi anak didik sebagai subjek belajar.

\section{b. Menurut Pandangan Ilmu Jiwa Modern}

Menurut konsepsi modern jiwa itu dinamis, mempunyai energi sendiri dan dapat menjadi aktif karena dorongan oleh macam-macam kebutuhan. Anak didik dipandang sebagai organisme yang mempunyai dorongan untuk berkembang. Mendidik adalah membimbing anak untuk mengembangkan bakatnya. Dalam pendidikan anak-anak sendirilah yang harus aktif. Guru hanya dapat menyediakan bahan pelajaran, akan tetapi yang mengolah dan mencernanya adalah anak itu sendiri sesuai dengan bakat dan latar belakang dan kemauan masing-masing. 


\section{Jenis-Jenis Aktivitas Belajar}

Sekolah adalah salah satu pusat kegiatan belajar, dengan demikian di sekolah merupakan arena untuk mengembangkan aktivitas. Banyak jenis aktivitas yang dapat dilakukan oleh siswa disekolah. Aktivitas siswa tidak cukup hanya mendengarkan dan mencatat seperti yang lazim terdapat disekolah-sekolah tradisional. Paul B. Diedrich dalam Sardiman (2011: 100) membuat suatu daftar kegiatan siswa yang antara lain dapat digolongkan sebagai berikut:

a. Visual activities, sikap ini ditunjukan dengan membaca.

b. Oral activities, sikap yang ditunjukan dengan menyatakan, merumuskan, bertanya, memberikan saran dan mengeluarkan pendapat.

c. Listening activities, ditunjukan dengan sikap mendengar, uraian, percakapan dan diskusi.

d. Writing activities, ditunjukan dengan sikap menulis, membuat karangan, laporan dan menyalin.

e. Drawing activities, ditunjukan dengan menggambar.

f. Mental activities, yang ditunjukan dengan sikap menanggapi mengingat, memecahkan soal, menganalisis, melihat hubungan dan mengambil keputusan.

g. Emotional activities, yang ditunjukan dengan sikap menaruh minat, merasa bosan, gembira, bersemangat, bergairah, berani, tegang dan gugup.

Klasifikasi sikap dan aktivitas seperti yang diuraikan diatas menunjukan bahwa aktivitas di sekolah cukup kompleks dan bervariasi. Jika sikap tersebut tercipta disekolahsekolah maka akan lebih mendinamiskan suasana pembelajaran, tidak membosankan dan benar-benar menjadi aktivitas belajar yang maksimal dan transformatif kebudayaan. Sehingga dengan karakteristik tersebut dapat menjadi indikator dan tolak ukur dalam mengukur sikap seorang siswa dalam kegaiatan pembelajaran. Sikap tersebut dapat dituangkan dalam beberapa hal, yaitu: kehadiran siswa di kelas, kelengkapan buku siswa, kesiapan siswa dalam pembelajaran, keaktifan atau rasio siswa dalam bertanya, keberanian dalam menampilkan hasil tugas kepada guru secara kelompok atau individu, menyatakan pendapat dan menerima kritikan.

\section{METODE}

Penelitian ini dilaksanakan pada SMP Negeri 1 Balai, jenis penelitian ini adalah penelitian eksperimental semu. Populasi penelitian ini adalah seluruh siswa kelas VIII dan kelas VIII-D yang terpilih sebagai sampel melalui teknik cluster random sampling. Metode pengumpulan data penelitian meliputi metode tes dan angket.

Sebelum melakukan eksperimen, dilakukan uji keseimbangan terhadap kemampuan awal matematika menggunakan ui-t. Data kemampuan pemecahan masalah matematika dianalisis menggunakan analisis variansi dua jalan dengan sel tak sama. Sebelumnya, terhadap data aktivitas maupun hasil belajar matematika dilakukan uji prasyarat meliputi uji normalitas populasi menggunakan metode Lillifors dan uji homogenitas variansi populasi menggunakan metode bartlett. Selanjutnya apabila hasil analisis variansi menunjukkan $\mathrm{H}_{0}$ ditolak, dilakukan uji komparasi ganda menggunakan metode Scheffe'.

\section{HASIL DAN PEMBAHASAN}

Rangkuman tes hasil belajar siswa (posttest) pada masing-masing kategori aktivitas dapat dilihat pada gambar 1 . 


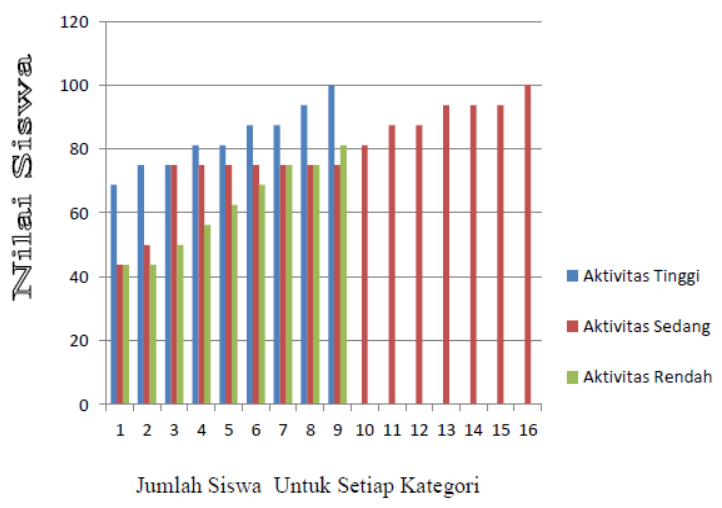

Gambar 1. Hasil belajar siswa

Sebelum dilakukan pengujian hipotesis, terlebih dahulu dilakukan uji prasyarat analisis berupa uji normalitas dan uji homogenitas. Berdasarkan perhitungan diperoleh bahwasanya sampel berasal dari populasi yang berdistribusi normal dan memiliki variansi yang sama. Selanjutnya dilakukan uji analisis variansi satu jalan dengan sel sama, berikut hasil yang diperoleh:

Tabel 1. Rangkuman anava satu jalan

\begin{tabular}{lcccccc}
\hline Sumber & JK & $\mathbf{d k}$ & $\mathbf{R K}$ & $\mathbf{F}_{\text {hitung }}$ & $\mathbf{F}_{\text {tabel }}$ & $\mathbf{P}$ \\
\hline Aktivitas & 2383 & 2 & 1191,5 & 187,5 & 3,32 & $<0,05$ \\
\hline Galat & 5812,6 & 31 & 187,5 & - & - & - \\
\hline Total & 8195,6 & 33 & - & - & - & - \\
\hline
\end{tabular}

Berdasarkan hasil analisis variansi satu jalan dengan sel tak sama diperoleh bahwa $\mathrm{H}_{0}$ ditolak, artinya terdapat perbedaan yang signifikan antara kategori aktivitas tinggi, sedang dan rendah setelah diberikan pembelajaran model Kooperatif Tipe NHT. Berdasarkan hasil penelitian dan pengujian hipotesis, berikut adalah penjelasan dari ketiga hipotesis penelitian:

\section{Hipotesis pertama}

Keputusan uji $\mathrm{H}_{01}=$ diterima, hasil penelitian ini tidak sesuai dengan hipotesis penelitian. Komparasi ganda pasca anava dengan metode Scheffe` menunjukan bahwa Fobs $<$ Ftabel, ini artinya tidak terdapat perbedaan yang signifikan antara hasil belajar siswa dengan kategori aktivitas tinggi dan siswa dengan kategori aktivitas sedang, hal ini disebabkan karena model pembelajaran kooperatif tipe NHT yang menuntut siswa dalam proses pembelajaran dalam keadaan siap dan sudah mengerti dengan tugas yang diberikan oleh guru kepada masing-masing kelompoknya, sehingga saat ditunjuk untuk mengerjakan tugasnya di depan, siswa tersebut bisa mengerjakanya baik itu yang tergolong kategori aktivitas tinggi maupun kategori aktivitas sedang. Dengan demikian, dapat disimpulkan bahwa hasil belajar siswa dengan kategori aktivitas tinggi sama baiknya dengan siswa dengan kategori aktivitas sedang.

\section{Hipotesis kedua}

Keputusan uji $\mathrm{H}_{02}=$ ditolak, hasil penelitian ini sesuai dengan hipotesis penelitian. Komparasi ganda pasca anava dengan metode Scheffe menunjukan bahwa Fobs $>$ Ftabel, ini artinya terdapat perbedaan yang signifikan hasil antara hasil belajar siswa dengan kategori aktivitas tinggi dan siswa dengan kategori aktivitas rendah, hal ini disebabkan 
oleh faktor aktivitas belajar siswa, siswa dengan kategori aktivitas tinggi lebih tinggi nilainya dari pada siswa dengan kategori aktivitas rendah. Hal ini karena siswa yang mempunyai aktivitas belajar tinggi akan berusaha semaksimal mungkin dalam belajar dan sangat antusias dalam mengerjakan suatu permasalahan yang diberikanoleh guru kepada mereka, daripada siswa yang mempunyai aktivitas belajar rendah. Hal ini sejalan bahwasanya siswa yang lebih tinggi aktivitasnya dalam proses belajar dimungkinkan memiliki hasil belajar yang lebih tinggi, sedangkan siswa yang pasif atau rendah aktivitasnya cenderung lebih sulit dalam mengikuti pembelajaran sehingga hasil belajarnya pun cenderung lebih rendah.

\section{Hipotesis Ketiga}

Keputusan uji $\mathrm{H}_{03}=$ ditolak, hasil penelitian ini sesuai dengan hipotesis penelitian. Komparasi ganda pasca anava dengan metode Scheffe $`$ menunjukan bahwa $\mathrm{F}_{\text {obs }}>\mathrm{F}_{\text {tabel }}$, ini artinya terdapat perbedaan yang signifikan antara hasil belajar siswa dengan kategori aktivitas sedang dan siswa dengan kategori aktivitas rendah, siswa dengan ketegori aktivitas sedang memilki hasil belajar yang lebih baik daripada siswa yang memiliki hasil belajar rendah, hal ini disebabkan oleh faktor aktivitas belajar, siswa dengan kategori aktivitas sedang biasanya memilki aktivitas yang sedikit lebih tinggi dari siswa yang memilki aktivitas rendah, sehingga hasil yang di peroleh oleh siswa yang memilki kategori aktivitas sedang lebih baik dari siswa yang memiliki aktivitas rendah.

\section{PENUTUP}

Dengan mengacu pada hasil temuan dan analisis variansi satu jalan sel tak sama, diperoleh simpulan bahwa:1) Hasil belajar pada siswa yang memiliki aktivitas belajar tinggi sama baiknya dari siswa yang memiliki aktivitas belajar sedang, 2) Hasil belajar pada siswa yang memiliki aktivitas belajar sedang lebih baik dari siswa yang memiliki aktivitas belajar rendah, dilihat dari rata-rata marginalnya yaitu 78,53 > 61,83, 3) Hasil belajar pada siswa yang memiliki aktivitas belajar tinggi lebih baik dari siswa yang memiliki aktivitas belajar rendah, dilihat dari rata-rata marginalnya yaitu 85,35 > 61,83.

\section{DAFTAR PUSTAKA}

Hamdani. 2010. Strategi Belajar Mengajar. Bandung: Pustaka Setia

Lie, A. 2010. Cooperative Learning Mempraktikkan Cooperative Learning di Ruang-Ruang kelas. Jakarta: Grasindo.

Ristika, N. 2007. Ilmu Pendidikan Teoritis dan Praktis. Bandung: Remaja Rosdakarya. Sardiman. 2011. Interaksi dan Motivasi Belajar Mengajar. Jakarta: PT Raja Grafindo Persada.

Slameto. 2003. Belajar dan Faktor-Faktor yang Mempengaruhinya. Jakarta: Raja Grafindo.

Trianto. 2010. Mendesain Model Pembelajaran Inovatif-Progresif: Konsep, Landasan, dan Implementasinya Pada Kurikulum Tingkat Satuan Pendidikan (KTSP). Jakarta: Kencana Prenada Media Group. 